\title{
Olof Hedling
}

\author{
Petr Szczepanik \& Patrick Vonderau: \\ Behind the Screen: Inside European Production Cultures. \\ New York: Palgrave Macmillan, 2013
}

MedieKultur 2015, 58, 169-172

Published by SMID | Society of Media researchers In Denmark | www.smid.dk The online version of this text can be found open access at www.mediekultur.dk

The collection Behind the Screen: Inside European Production Cultures is a contribution to the growing field of inquiry that has been called production studies or sometimes media industries studies. Moreover, as the title's monikers "inside" and "culture" suggests, several chapters of the anthology draw on anthropological observation. Accordingly, some of the participating scholars have visited writers' rooms, shooting sets and/or conducted interviews with various forms of audiovisual practitioners.

Although very welcome, Behind the Screen is not the first of its kind but rather part of a suddenly appeared boom in research publications on industry. Furthermore, the boom has been described in terms of an "industrial turn" or "industrialization" within film and media studies. Despite this designation, however, the issues under inquiry are not entirely new. Some of them have been dealt with previously and for quite some time (see for instance Bordwell, Thompson and Staiger's The Classical Hollywood Cinema: Film Style and Mode of Production to 1960 (1985) or Thomas Schatz' The Genius of the System (1988)). To some extent, the perceived turn rather epitomizes a break with the long standing focus within film studies on matters such as authorship debates as well as text-centric criticism of symbolic artifacts aiming to interrogate matters of meaning and representation. Within this tradition, a more multi-faceted view of industry was and is, more often than not, simply not a concern.

Addressing this neglect of sorts, Behind the Screen consists of explorations of how particular national film- and television-making environments work, of the trajectory of a single 
film's production as well as of such matters as the wider economic, social and geographical circumstances in which creative work is undertaken in various European territories (in addition, there are also a couple of excursions outside the continent). What is at stake, in one sense, are both presently and historically inclined investigations into the many backgrounds - be they economic, collaborative and creative, politically imposed or sociological - through which audiovisual works are created in Europe.

This means that there are texts dealing with such matters as the regional, contemporary attempts at film- and television production in Glasgow in Scotland, as well as the general underrepresentation of women, ethnic minorities and people from lower socioeconomic backgrounds not only in film but in broadcasting, advertising and new media in general. Another contribution concerns the obstacles of Nollywood diaspora video filmmakers who are trying to get ahead within Europe's production models by emphasizing the national, state subsidies, theatrical distribution as well as the many and particular languages.

Among the European nations, Denmark is given a prominent place with three of the thirteen contributions devoted to present Danish circumstances. Oscars, early Lars von Trier and Dogme 95 in the 1990s earned the small Scandinavian country a place on the map. However, the present surge in the production of television serials and feature films along with the concurrent maturing of talents like said von Trier, Susanne Bier as well as the many writers responsible for series like The Killing (Forbrydelsen, 2007-2012) and Borgen (2010-), is responsible for Denmark and Danish having become catchwords in relation to film and television production.

Two of these papers are dominated by perspectives and discussions infused by contrasting theories of the sociology of art, while the ultimate empirical conclusions appear somewhat modest. This description is not meant to be derogatory since both texts more or less clearly imply their theoretical and methodological concerns as being, if not paramount then at least, of equal importance to their interest in the workings of the Danish industry. Nonetheless, we learn that the belief in the "auteur ideology" prevails in feature film-making and that social relationships influence the outcome of cultural production. This is all fine even if the deductions seem slightly diluted. After all, does such characterizations not hold true for a vast majority of present European, national film-making discourses?

In Eva Novrup Redvall's dense contribution, the development of contemporary Danish television series and its increasing domestic and international popularity is scrutinized. The article combines institutional history of the state broadcaster DR's Fiction department and the particular mode of production that has been developed - codified as "One Vision" using a set of "Dogmas" as guiding principles. This mode, in turn, is compared and contrasted with the parallel rise of the figure of the show runner in the US television industry since the 1990s (say, David Chase of The Sopranos (1999-2007) or Amy Biderman of Ray Donovan (2013-)). Redvall concludes her essay by discussing diverse forms of auteurs and authorship within the cross-continental cultures of the television series, a form that, on the one hand, is often considered to experience a golden age and, on the other hand - just like 
feature films - struggles with its business models in an increasingly competitive, converging media environment marked by swift technological transformations. The essays on the Danish industry represent diverse but productive approaches to a small European industry which, to an extent, has made its mark outside its domestic borders, an achievement that many comparable European equivalents has not succeeded with.

A critique, which is sometimes directed towards media industries studies, concerns its supposed fixation with the here and now, with what might be called nowness. To some extent, this applies to Behind the Screen as well in the sense that a majority of the contributions deals with comparatively recent events and conditions. Four contributions, however, have decidedly historic aims; such as Daniel Steinhart's study based on thorough archival research on how Hollywood studios came up with operational ways of organizing European location shootings during the decades following WWII. During this period, Rome gained its reputation as Hollywood on the Tiber. It was also a time when West Coast A-list figures such as Alfred Hitchcock shot large scale titles such as To Catch a Thief (1955) and The Man Who Knew Too Much (1956) mainly on European soil. Eventually, this development led several of the studios to set up production offices in some of the European capitals. In brief, Steinhart's essay traces the early development of the production side of what is increasingly called Global Hollywood. These production practices started six or seven decades ago and have become more and more common, not least since the fall of the Iron Curtain and the rise of runaway production in the territories formerly located behind that tragic demarcation line.

Another historic endeavor is Petr Szczepanik's examination of the nationalized production systems of Czechoslovakia during the period of state socialism as enforced by the Communist authorities. As was the case in several of the Soviet Bloc countries, film production was organized in a system in which units were attached to a specific studio. More specifically, the attempt is to interrogate the specifics of the top-down ideological and aesthetic control mechanism of these units, called "dramaturgy". Somewhat similar systems were implemented in almost all of the Bloc states and had previously been in use in Nazi Germany. Szczepanik, however, maps out the particular national implementation and explains how its workings shifted during times of thaw and the famed Czechoslovak New Wave of the 1960s. These, and the other two historical surveys in the volume, come across, at least to this reader, as particularly valuable contributions.

In a recent issue of Cinema Journal (3/2013, pp. 145-189), a section was devoted to the rise of media industries studies (MIS). Here, a number of scholars were invited to reflect on the current and future state of MIS and implicitly, to represent and point out a number of differing and at times conflicting stakes and approaches. The perspectives vacillated from somewhat traditional political economy to pleas for not leaving out the critical cultural theory of much past film studies, as well as much else.

Besides having a European focus, Behind the Screen takes sides in this slight dispute, joining the line of inquiry defended by UCLA scholar John T. Caldwell in the abovemen- 
tioned section. Thus, the book, and especially its introduction, appears to attempt to align itself with a continuation of the designs of 'Theory', or occasionally and controversially, when pertaining to Anglo-American film studies particularly, Grand Theory. This strand of inquiry came into prominence in the 1970s through the British journal Screen and was heavily indebted to continental critical theory in general as well as to its various structuralist and, later on, poststructuralist permutations. Consequently, in the somewhat solemn introduction of Behind the Screen, the word Marx (or derivations thereof such as Marxist, Marxian and so forth) is mentioned in each of the five first paragraphs. In between these mentions, accustomed references to Raymond Williams, Jean-Louis Comolli and Pierre Macherey, as well as marker words such as "late capitalism", pop up.

Accordingly, Behind the Screen promotes a particular scholarly agenda regarding academic politics, methodology and certain views on the theories of the humanities and social sciences. This gives the book a focus and a clear mission although it may not be to everyone's liking. Still it must be said that the volume is an important and considerable contribution to the emerging field of European media industries studies.

Olof Hedling, PhD

Associate Professor

Department of Languages and Literature

University of Lund, Sweden

Olof.Hedling@litt.lu.se 